\title{
Strategi Pengembangan Pariwisata Provinsi Papua
}

jurnal.kemendagri.go.id/index.php/ $\mathrm{mp}$

e-ISSN: 2549-5283

p-ISSN: 2549-5151

Matra Pembaruan 4 (1) (2020):

59-69

DOI:-

10.21787/mp.4.1.2020.59-69

Keywords: Development, Tourism, Tourism Potential

Kata Kunci: Pengembangan, Pariwisata, Potensi Wisata

\section{*Korespondensi \\ Phone : +6285244741131 \\ Email : ismailfolaimam@yahoo. \\ co.id}

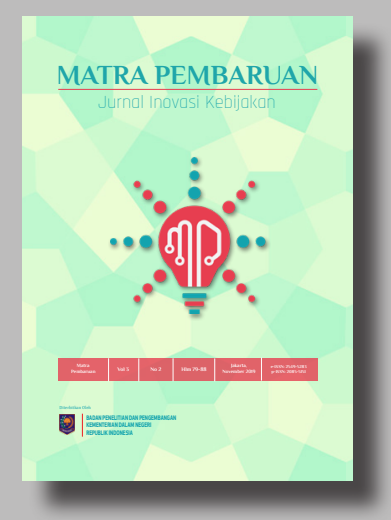

BADAN PENELITIAN DAN PENGEMBANGAN (BPP) KEMENTERIAN DALAM NEGERI

Jl. Kramat Raya No 132, Jakarta Pusat, 10450

(C)Muhamad Ismail

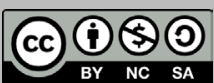

Karya ini dilisensikan di bawah Lisensi Internasional Creative Commons Atribusi Nonkomersial Sharealike 4.0 .

\author{
Muhamad Ismail ${ }^{*}$ \\ Badan Penelitian dan Pengembangan Daerah Provinsi Papua \\ Jalan Raya Abepantai No.26 Abepura Jayapura
}

Dikirim: 29 Januari 2020; Direvisi: 23 April 2020;

Disetujui: 5 Mei 2020

\begin{abstract}
Tourism is a potential sector and deserves to be developed innovatively to increase the level of competitiveness. Papua is a province that has a huge tourism potential. But the reality is not managed properly, so that it impacts on socio-economic conditions. People who live in the area are generally still poor. For this reason, this research is very important to be carried out so that changes occur in terms of increasing regional income, tourist visits and the value of tourism promotion that is getting better. The purpose of this study is to formulate a strategy for developing tourism potential in Papua Province through a SWOT analysis. The research also uses descriptive methods through a qualitative approach with its informants namely universities, Bappeda, Balitbangda, Tourism Office, Industry and Trade Office, Regional Revenue Service, Labor Agency, Customary Figure, Religious Figure, UKM Cooperative Office, Culture Office, Social Service, Department of Education and NGOs. The results showed that the management of natural attractions in Papua in general are still managed traditionally and managed by indigenous peoples. One obstacle to tourism development in Papua is the unavailability of the Regional Tourism Master Plan, the lack of promotion of natural and cultural tourism, the high migration to Papua, and the unstable security conditions. The annual tourism activities are only routine activities and have not had an economic impact (multiple effects). For this reason, it is needed a strategy to develop the potential of natural tourism in order to preserve natural resources and maintain a conducive tourism climate.
\end{abstract}

\section{Intisari}

Pariwisata adalah sektor yang potensial dan layak untuk dikembangkan secara inovatif guna meningkatkan tingkat daya saing. Papua adalah provinsi yang memiliki potensi pariwisata yang sangat besar. Namun kenyataannya belum dikelola dengan baik, sehingga berdampak pada kondisi sosial ekonomi. Masyarakat yang berdomisili di wilayah tersebut yang pada umumnya masih miskin. Untuk itu maka penelitian ini sangat penting untuk dilaksanakan supaya terjadinya perubahan dalam hal peningkatan pendapatan daerah, kunjungan wisatawan dan nilai promosi wisata yang semakin baik. Tujuan kajian ini adalah merumuskan strategi pengembangan potensi pariwisata di Provinsi Papua melalui analisis SWOT. Penelitian juga menggunakan metode deskriptip melalui pendekatan kualitatif dengan Informannya yaitu perguruan tinggi, Bappeda, Balitbangda, Dinas Pariwisata, Dinas Perindustrian dan Perdagangan, Dinas Pendapatan Daerah, Dinas Tenaga Kerja, Tokoh Adat, Tokoh Agama, Dinas Koperasi UKM, Dinas Kebudayaan, Dinas Sosial, Dinas Pendidikan dan LSM. Hasil penelitian menunjukkan bahwa pengelolaan obyek wisata alam di Papua pada umumnya masih dikekola secara tradisional dan dikelola masyarakat adat. Salah satu kendala pengembangan wisata di Papua adalah belum tersedianya Rencana Induk Pariwisata Daerah, kurangnya promosi wisata alam dan budaya, tingginya migrasi ke Papua, serta kondisi keamanan yang belum stabil. Adapun kegiatan wisata tahunan hanya kegiatan rutinitas dan belum memberikan dampak ekonomi (efek berganda). Untuk itu, diperlukan strategi pengembangan potensi wisata alam supaya menjaga kelestarian sumber daya alam dan terjaganya iklim pariwisata yang kondusif. 


\section{Pendahuluan}

Potensi pariwisata yang dimiliki Provinsi Papua hampir terlengkap di Indonesia. Alam yang dimilikinya masih asli, budaya yang khas dan unik, menjadi daya tarik tersendiri. Destinasi wisata di Provinsi Papua telah menyumbang 25\% terhadap total kunjungan wisatawan secara nasional per tahun. Potensi bisnis wisata di provinsi Tanah Papua itu sangatlah besar karena memiliki kekhasan dan keotentikan budaya (Petriella, 2018). Papua memiliki modal yang kuat untuk mengembangkan pariwisatanya asalkan Papua dapat menata, mengelola dan mengunggulkan keunikan dan karakteristik sumber daya alam di daerahnya. Saat ini Provinsi Papua menyadari keunggulan daerahnya, akan tetapi Papua belum menjadikan pariwisata sebagai prioritas pembangunan. Provinsi Papua hanya memprioritaskan penganggaran dalam rangka mempersiapkan penyelenggaraan PON (Loen, 2019). Prioritas tersebut merupakan hasil kesepakatan pemerintah Provinsi, Kabupaten dan Kota sekaligus merupakan suatu kebutuhan yang harus dilakukan, bukan berdasarkan satu keinginan. Ungkapan ini sangat menarik, ketika Rencana Kerja Pemerintah 2020 mentargetkan lima unsur prioritas pembangunan yaitu (1) pembangunan manusia dan pengentasan kemiskinan; (2) infrastruktur dan pemerataan wilayah; (3) nilai tambah sektor riil, industrialisasi dan kesempatan kerja; (4) ketahanan pangan, air, energi dan lingkungan hidup; dan (5) stabilitas pertahanan dan keamanan (bappenas, 2019). Namun Provinsi Papua memenuhi alokasi anggaran untuk kegiatan yang insidentil salah satunya pelaksanaan Pekan Olahraga Nasional (PON) 2020.

Belum terakomodasi pariwisata dalam prioritas pembangunan, sungguh sangat disayangkan. Potensi-potensi alam yang ada di Provinsi Papua akan tergeser oleh waktu. Padahal bila ditelusuri secara mendetail, Papua dikunjungi hanya dikunjungi 41.425 wisatawan mancanegara. Kunjungan wisatawan tersebut masih kurang dari target kunjungan turis mancanegara ke Indonesia sebanyak 20 juta wisatawan yang diharapkan Kementerian Pariwisata (Agmasari, 2019). Wisatawan masih mengenal tempat wisata lainnya di luar Provinsi Papua seperti Provinsi Papua Barat dikenal dengan Raja Ampatnya, Yogyakarta dengan Candi Borobudurnya, dan sebagainya. Hal ini membuktikan bahwa Provinsi Papua secara promosi wisata belum dikenal publik terutama eksotisme dan daya wisata yang dimiliki. Keberadaan wisata Provinsi Papua menjadi penting, ketika wisatawan berbondong-bondong mendatangi suatu daerah baik itu untuk refreshing ataupun perjalanan bisnis menandakan daerah tersebut sudah memberikan kepercayaan kepada publik bahwa Provinsi Papua layak diperhitungkan sebagai daerah yang memberikan peluang besar bagi masyarakat untuk berkunjung kesana. Kunjungan wisatawan ke Tanah Papua kecil sekali, karena turis lebih banyak ke Bali, Jakarta, dan Batam. Untuk ke Tanah Papua membutuhkan biaya transportasi yang mahal (Rumpaidus et al., 2019, p. 32). Jauh lebih murah kalau ke Singapura atau Jepang bagi wisatawan. Pernyataan ini sangat ironis di mana Provinsi Papua tidak kalah memiliki aset sumber daya alam yang berlimpah namun kurang dalam hal pengelolaannya. Bila dibiarkan tanpa atensi dari pemerintah daerah setempat, hal ini tidak mustahil pariwisata Provinsi Papua hanya tinggal sejarah.

Pengelolaan wisata di Provinsi Papua saat ini perlu pembenahan secara intensif dan profesional. Bila melihat kecilnya kuantitas pengunjung yang berwisata ke Provinsi Papua menjadi tantangan buat pemerintah daerah Provinsi Papua untuk mengembangkan pariwisata yang ada. Kajian Primadany (2013, p. 136), menyatakan, sektor pariwisata memerlukan strategi dengan pola pengembangan kepariwisataan yang terencana atau tersusun agar potensi yang dimiliki bisa di kembangkan secara optimal. Potensi daerah menjadi aset terpenting untuk dapat tereksplorasi dengan baik, di mana daerah memiliki keunggulan budaya, keunggulan sumber daya alam sehingga pesonanya dapat menjadikan pariwisata sebagai tuan rumah dalam meningkatkan perekonomiannya. Maksudnya adalah potensi daerah dapat menjadi indikator keberhasilan utama dalam menerapkan strategi pengelolaan pariwisata di Provinsi Papua. Contohnya budidaya kakao dengan sentuhan inovasi dapat memiliki nilai jual di negri sendiri, Taman Nasional Wasur di Merauke dengan berbagai spesies mamalia, Taman Nasional Teluk Cenderawasih dengan konsep manajemen industri pariwisata yang kekinian dapat merubah daya tarik wisatawan dengan mengadakan atraksi yang menghibur pengunjung (Flo, 2018). Sektor pariwisata sudah terbukti mampu memberikan kontribusi yang signifikan dalam pembangunan ekonomi nasional sebagai industri perolehan devisa. Oleh karenanya dengan pengelolaan yang tidak meninggalkan kearifan lokal, dapat berindikasi pada terbangunnya sarana dan prasarana yang lebih memadai dengan syarat pertama memiliki keunikan atau identitas daerah tersebut, kedua tempat wisata memberikan keamanan, kenyamanan dan keselamatan, ketiga dukungan dari pemerintahan daerah dan masyarakat setempat. Sebagaimana yang dikemukakan Subardin dkk (2010, p. 16) beberapa unsur yang harus terpenuhi sebagai destinasi wisata yaitu daya tarik, aksesibilitas, infrastruktur dan pemberdayaan masyarakat.

Bila kita melihat dari segi potensi pariwisata Provinsi Papua sudah tidak kalah hebatnya dengan daerah lain, namun pada kenyataannya mereka 
dihadapkan pada permasalahan sebagai berikut (1) keterbatasan akses transportasi yang sulit terjangkau dan menelan biaya yang mahal,(2) kurang menariknya pengemasan produk yang ditawarkan dan minimnya amenitas di lokasi destinasi wisata, (3) belum maksimalnya pemanfaatan teknologi informasi untuk mengembangkan sektor pariwisata, maupun (4) belum adanya sinergitas antara pemerintah dengan stakeholders pariwisata di daerah mengakibatkan daya tarik pariwisata menjadi rendah (papuabangkit.com, 2017). Begitu pula hasil kajian Nurhayati dan Ristanto (2017) yang menyatakan, masih banyak tempat-tempat wisata Provinsi Papua yang patut dikunjungi. Namun kurangnya informasi mengenai tempat wisata tersebut menjadikan Provinsi Papua minim pengunjung. Artinya permasalahan yang dihadapi Provinsi Papua bukanlah sebuah perkara yang mudah untuk diselesaikan. Banyak hal yang harus dibenahi mulai dari infrastruktur, sistem promosi wisata, edukasi masyarakat menjadi tantangan untuk memajukan pariwisata di Provinsi Papua.

Secara teori, daerah yang memiliki Sumber Daya Alam (SDA) yang besar, mampu menjadi daerah yang maju dengan diiringi SDM yang berkualitas tinggi. Permasalahan di atas juga terkait dengan pembangunan daerah (otonomi daerah). Pengembangan suatu daerah perlu dilakukan secara terus-menerus dan berkesinambungan. Hal tersebut melibatkan berbagai potensi sumber daya yang dimiliki dan dapat memberikan kontribusi bagi perkembangan daerah-daerah sekitarnya. Potensi yang dapat dijadikan sebagai sumber pengembangan antara lain sumber daya alam (natural resources), sumber daya manusia (human resources) dan sumber daya budaya.

Pitana dan Diarta (2009) menyatakan bahwa pariwisata berdampak pada penerimaan devisa, pendapatan pemerintah, harga-harga, distribusi manfaat/keuntungan, kesempatan kerja kepemilikan dan kontrol. Sebagaimana hasil kajian dampak positif daya tarik wisata "hot spring" Marobo dengan adanya kegiatan pariwisata maka tercipta pula lapangan kerja untuk masyarakat sekitar yang di mana dapat menguntungkan bagi masyarakat lokal, pembangunan pada umumnya, dan pendapatan masyarakat (Pieda \& Anom, 2019). Dampak tersebut menjadi sebuah pemikiran untuk membuat alur pengembangan pariwisata di Provinsi Papua.

Pada dasarnya pariwisata di Papua menampilkan Taman Nasional Wasur di Merauke dengan berbagai spesies mamalia, Taman Nasional Teluk Cenderawasih dengan berbagai biota laut dan karang yang indah serta tidak ketinggalan pula potensi budaya yang biasanya ditampilkan pada Festival Lembah Baliem dan Asmat serta kegiatan pariwisata lainnya berupa trekking, hiking, hunting dan adventure. Jenis-jenis pariwisata tersebut bisa bertambah, tergantung pada kondisi dan situasi perkembangan dunia kepariwisataan di suatu daerah. Hal ini berkaitan dengan kreativitas para ahli profesional yang berkecimpung dalam industri pariwisata. Semakin kreatif dan banyak gagasan yang dimiliki, maka semakin bertambah pula bentuk dan jenis wisata yang dapat diciptakan bagi kemajuan industri pariwisata. Oleh karenanya pengembangan pariwisata Provinsi Papua menjadi perlu diperhatikan mengingat dalam realitasnya keanekaragaman budaya Papua secara nyata belum menampakkan dan belum diketahui secara publik.

Pengembangan pariwisata menurut Suswantoro (2004) dalam pengembangan pariwisata harus dilakukan melalui: a. Promosi, merupakan pelaksanaan upaya pemasaran yang harus dilaksanakan secara terpadu baik di dalam maupun diluar negeri; b. Aksebilitas, merupakan salah satu aspek penting yang mendukung karena menyangkut pengembangan lintas sektor, dan ; c. Kawasan pariwisata. Ketiga inilah yang nantinya sebagai solusi dalam mengembangkan aspek kepariwisataan di Indonesia.

Suwantoro (2004) mendefinisikan pariwisata sebagai suatu perubahan tempat tinggal sementara seseorang di luar tempat tinggalnya karena suatu alasan dan bukan untuk melakukan kegiatan yang menghasilkan upah. Artinya, kegiatan pariwisata adalah kegiatan yang dilakukan di luar rutinitas sehari-hari. Sebagaimana UU No 10 tahun 2009 tentang Kepariwisataan menjelaskan, pariwisata merupakan salah satu bentuk industri yang tumbuh, berkembang dan memiliki prospek sebagai peluang baru berkembangnya usaha pariwisata dan sektor-sektor lain yang terkait kepariwisataan yaitu usaha-usaha yang memberikan fasilitas dan layanan kebutuhan wisatawan. Usaha-usaha yang potensial berkembang antara lain adalah: perjalanan wisata seperti jasa tour, biro perjalanan, usaha akomodasi seperti hotel, home stay dan jenis penginapan lainnya, restoran, usaha hiburan, jasa impresariat, perbankan, usaha penukaran valuta asing, serta usaha atraksi wisata lain yang unik. Penekanan pengembangan usaha pariwisata ini dapat dimiliki dan dikelola oleh masyarakat, pengusaha, pemerintah dan pemerintah daerah dalam bentuk pengelolaan usaha mandiri maupun pengelolaan dalam bentuk kerjasama antar pemilik dan pengelolaan berbagai pihak atau stakeholder yang pada akhirnya memberikan prospek tumbuh kembangnya perekonomian daerah dengan tujuan mensejahterakan masyarakat.

Kebijakan publik bidang pariwisata juga akan ditentukan oleh lingkungan politik (Pathurrahman, 2015, p. 31). Kinerja kebijakan akan dipengaruhi oleh konteks politik tempat dimana kebijakan tersebut diimplementasikan. Lingkungan kebijakan 
seperti adanya gejolak politik akan mempengaruhi dan memaksa pelaku atau aktor kebijakan publik meresponsnya yakni memasukkannya ke dalam agenda pemerintah dan selanjutnya melakukan kebijakan pulik untuk memecahkan masalahmasalah yang bersangkutan.

Untuk itu, kajian ini akan mengulas strategi pengembangan pariwisata di Provinsi Papua dengan mencermati dari aspek kelemahan, kekuatan, peluang dan ancaman. Kajian ini juga berbeda dari kajian yang lainnya, terutama dalam hal bagaimana mengembangkan potensi pariwisata Papua melalui strategi pengembangan sesuai dengan kearifan lokal yang ada. Keunikan kajian ini adalah keberanian penulis untuk mengangkat penguatan sektor pariwisata tidak hanya dari tataran regulasi, namun bagaimana Provinsi Papua dapat menciptakan inovasi di bidang pariwisata melalui penguatan regulasi dan manajemen pariwisata. Oleh karenanya tujuan kajian ini adalah untuk mengetahui bagaimana strategi untuk mengembangkan pariwisata di Provinsi Papua.

\section{Metode}

Metode yang digunakan dalam penelitian ini adalah analisis deskriptif dengan pendekatan kualitatif. Di sini penulis menggambarkan pariwisata di Provinsi Papua termasuk juga mengidentifikasi kekuatan, kelemahan, peluang dan ancaman yang di hadapi Provinsi Papua. Cara ini dianggap penulis sangat tepat, mengingat dengan diketahuinya faktor tersebut akan memudakan penulis untuk membuat skema pengembangan pariwisata di provinsi Papua. Teknik pengumpulan datanya dengan observasi ke titik pariwisata di Provinsi Papua dan pariwisata di sekitar Kota Jayapura yaitu Pantai Base'G, Teluk Yoteva, dan Pantai Hamadi. Pemilihan lokasi wisata dengan pertimbangan potensi wisata alam di Kota Jayapura yang belum terkelola dengan baik, karena masih dikuasai pemilik hak ulayat.

Wawancara dilakukan ketika FGD berlangsung dengan informan yang terlibat yaitu perguruan tinggi, Bappeda, Balitbangda, Dinas Pariwisata, Dinas Perindustrian dan Perdagangan, Dinas Pendapatan Daerah, Dinas Tenaga Kerja, Tokoh Adat, Tokoh Agama, Dinas Koperasi UKM, Dinas Kebudayaan, Dinas Sosial, Dinas Pendidikan dan LSM. Selain itu, penulis memperoleh data sekunder berdasarkan dari situs internet, perpustakaan dan hasil kajian terdahulu sebagaimana yang sudah diulas dalam latar belakang masalah dan pembahasan dalam kajian ini.

Teknik analisa datanya dengan analisa SWOT. Secara teori SWOT adalah akronim dari strengths (kekuatan), weaknesses (kelemahan), opportunities (peluang), dan threats (ancaman), dimana SWOT dijadikan sebagai suatu model dalam menganalisis suatu organisasi yang berorientasi pada profit dan non profit dengan tujuan utama untuk mengetahui keadaan organisasi tersebut secara lebih komprehensif (Fahmi \& Yunus, 2013, p. 252). Dalam hal ini penulis mengidentifikasi kekuatan, kelemahan, peluang dan ancaman yang ditemui ketika turun ke lapangan. Analisis ini menempatkan situasi dan kondisi sebagai faktor masukan, kemudian dikelompokkan sesuai dengan SWOT (Lihat Atmoko, 2014). Selanjutnya dari hasil pemetaan tersebut penulis membuat alur pengembangan pariwisata berdasarkan strategi pengembangan pariwisata di Provinsi Papua. Alur pariwisata akan ditekankan pada aspek regulasi dan manajemen. Kedua itulah yang selama ini menjadi pemicu dari masalah pariwisata di Provinsi Papua.

\section{HASIl DAN PEMbahasan}

Potensi wisata adalah semua obyek (alam, budaya, buatan) yang memerlukan banyak penanganan agar dapat memberikan nilai daya tarik bagi wisatawan. Eksplorasi potensi dimulai dari penjelajahan keunggulan yang dapat dikembangkan. Misalnya, Papua sebagai penghasil Kakao, bagaimana menjadikan Kakao di Papua berbeda dengan daerah penghasil lainnya. Maknanya adalah keunggulaan Provinsi Papua sangat penting untuk di bahas dan diketahui publik. Dimana pengelolaan untuk mengembangkan potensi obyek wisata menjadi agenda besar bagaimana menciptakan pariwisata sesuai dengan harapan masyarakat yaitu aman, nyaman dan murah.

Pada prinsipnya kontribusi sektor pariwisata terhadap perekonomian Provinsi Papua masih rendah dibandingkan dengan potensi pariwisata yang dimilikinya. Wisatawan asing maupun domestik yang berkunjung ke Papua belum begitu besar. Salah satu penyebab peningkatan jumlah kunjungan yang tidak signifikan adalah terkendala biaya transportasi yang sulit untuk menjangkau lokasi wisata. Pertimbangan faktor biaya karena sulitnya transportasi menjadi salah satu kendala bagi wisatawan yang berkunjung ke Papua (Prakoso, 2015). Berdasarkan data perbandingan kunjungan wisatawan dari tahun ke tahun sekaligus rata-rata tamu menginap sebagai berikut :

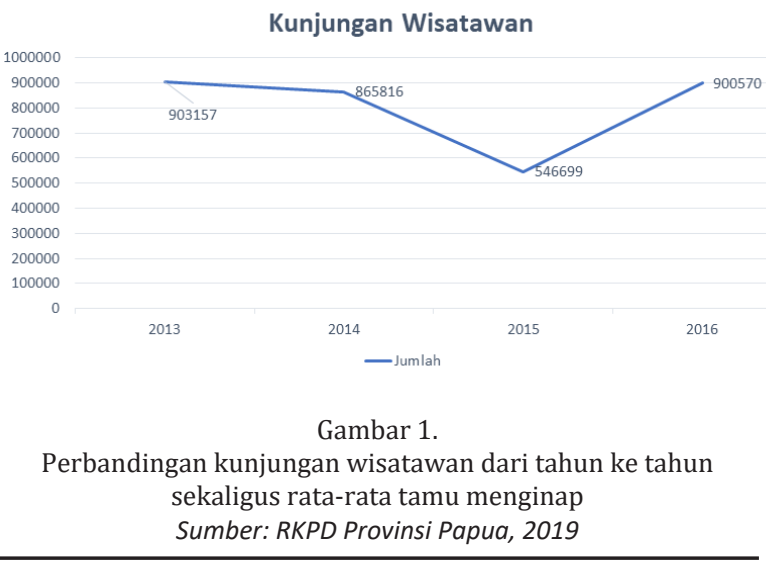

Matra Pembaruan 4 (1) (2020): 59-69 
Kunjungan wisatawan mengalami perubahan setiap tahunnya. Pada 2015 pengunjung mengalami penurunan sangat drastis menjadi 546.699. Kemudian pada 2016 mengalami peningkatan kembali sebanyak 900.570. Sedangkan untuk ratarata tamu menginap di sekitar Provinsi Papua dapat dilihat di bawah ini :

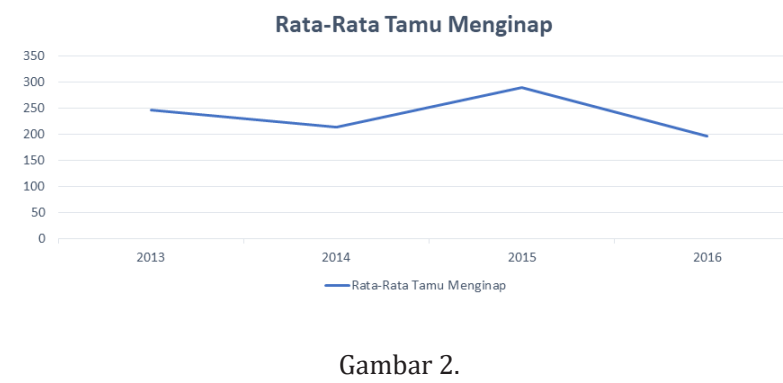

Rata-rata tamu menginap di sekitar Provinsi Papua Sumber: RKPD Provinsi Papua, 2019

Untuk rata-rata lama tinggal wisatawan perkembangannya terlihat fluktuatif karena sempat menurun pada 2014. Kemudian pada 2013 ratarata lama tinggal wisatawan yaitu selama 2,46 hari, turun menjadi 2,14 hari di 2014 dengan rata-rata pertumbuhan $-3,30 \%$ per tahun.

Beberapa hal yang menjadi penyebabnya di anyaranya; pertama fasilitas. Pengelolaan yang baik pada tiap obyek wisata sangat diperlukan untuk mengidentifikasi dan meningkatkan kualitas sarana dan prasarana yang diperlukan pada tiap obyek wisata. Dengan peningkatan kualitas sarana dan prasarana diharapkan dapat meningkatkan arus kunjungan wisatawan sehingga sektor pariwisata mampu memberikan berkontribusi terhadap peningkatan perekonomian masyarakat.

Pada dasarnya fasilitas yang tidak memadai menjadi penghalang sebuah daerah untuk maju pembangunannya. Pada umumnya beberapa hal yang belum berjalan optimal dari pengembangan wisata di antaranya akses jalan, sarana, SDM, dan regulasi pariwisata (Itamar et al., 2014, p. 95). Selain itu, pengembangan destinasi pariwisata masih minim karena kurangnya perawatan pada setiap fasilitas yang ada, kurangnya pendidikan serta pelatihan yang dilaksanakan kepada pegawai dan pengelola yang ada di lapangan (Ervina, 2017, p. 6241). Hal itu menegaskan fasilitas yang terdapat di pariwisata menjadi salah satu daya tarik bagi para pengunjung.

Kedua, Kebijakan Pemerintah Provinsi Papua sangat berpengaruh terhadap perkembangan pariwisata daerah. Misalnya, Primadany (2013) mengatakan, Kabupaten Nganjuk mengalami penghambatan pariwisatanya karena belum tersedianya peraturan daerah yang mengatur tentang strategi pengembangan pariwisata di Kabupaten Nganjuk. Contoh lain, Nurhadi, Mardyono, dan Rengu (2014) menemukan tiga strategi yang dilakukan Kabupaten Mojokerto dalam pengembangan pariwisata di daerah yaitu pengembangan obyek wisata, promosi wisata, dan pembinaan usaha pariwisata. Penegasan hasil kajian tersebut menggambarkan, pemerintah daerah tidak bisa berpaling untuk mengabaikan pariwisata yang ada di daerahnya.

Begitu juga berdasarkan hasil penelitian di lapangan, penempatan prioritas pembangunan dari Pemerintah Provinsi Papua terhadap bidang pariwisata masih relatif kecil dan masih jauh di bawah, jika dibandingkan dengan bidang lain seperti pendidikan dan kesehatan. Belum ditempatkannya sektor pariwisata sebagai salah satu prioritas utama pembangunan daerah di era otonomi khusus ini menjadikan banyak usulan program yang telah direncanakan menjadi sulit terealisasi. Prioritas pembangunan yang sangat kecil yang dilakukan Provinsi Papua menjadi ukuran dan sebuah permasalahan, hal ini dikarenakan secara kuantitas jumlah wisatawan yang berkunjung sangat minim. Akibatnya pariwisata tidak menjadi skala prioritas di Provinsi Papua. Padahal, skala prioritas menjadi kebutuhan mutlak yang harus diambil guna mengakomodasi usulan yang paling memberikan manfaat dengan dampak skala prioritas, dengan mempertimbangan spesifikasi potensi wilayah yang dipadukan tingkat kebutuhan masyarakat, maupun pertimbangan lain yang ditinjau dari aspek sosio politik, tekhnologi, partisipasi, dan kebijakan (TR01, 2019).

Tidak hanyaitu, Provinsi Papua terkendala pada sistem promosi pariwisata dinilai kurang inovatif. Masih kurangnya promosi dan inovasi pariwisata disebabkan belum ditempatkannya pariwisata sebagai salah satu prioritas pembangunan dari pemerintah daerah sehingga dana yang dianggarkan masih belum mencukupi untuk mengembangkan produk-produk wisata yang akan dipasarkan atau dipromosikan. Sebagaimana Prantawan dan Sunarta (2015) menyatakan terdapat dua potensi wisata di Tabanan yaitu potensi budaya dan potensi alamiah yang dapat dijadikan daya tarik ekowisata namun masih kurangnya promosi terhadap potensi. Artinya bahwa promosi wisata juga mutlak memasukkan potensi andalan daerah.

Promosi dan inovasi pariwisata harus didukung dengan ketersediaan sarana dan prasarana yang menarik dalam obyek wisata, sehingga mampu mempengaruhi pengunjung untuk datang. Pelaksanaan strategi atau program pengembangan pariwisata merupakan berbagai gambaran strategi untuk pengembangan potensi pariwisata yang telah diterapkan di Provinsi Papua. Strategi tersebut terbentuk dengan memanfaatkan sumber daya, dana/anggaran, dan sarana dan prasarana yang 
dimiliki untuk melaksanakan pengembangan potensi pariwisata. Menurut pendapat salah satu responden Dinas Pariwisata Provinsi Papua, bahwa strategi yang telah dilakukan Papua lebih terfokus pada dua program yaitu destinasi pariwisata dan pemasarannya. Perencanaan dan pelaksanaan strategi atau program-program yang ditempuh terpengaruh pada dana yang dianggarkan oleh pemerintah daerah.

Pemerintah daerah mulai membuka diri dengan stakeholder yang terkait seperti membuka komunikasi dan pelibatan dalam penyusunan program pengembangan pariwisata maupun promosinya serta menyiapkan sumber daya manusia yang andal dalam bidang pariwisata seperti dengan biro perjalanan, perhotelan, dan juga dengan pihak ketiga yang lain. Kerja sama ini sangat diperlukan untuk meningkatkan kualitas pariwisata di Provinsi Papua. Karena dalam usaha pengembangan pariwisata diperlukan kerja sama dengan berbagai pihak, dan termasuk juga dengan pemangku kepentingan bidang pariwisata atau stakeholder bidang parwisata. Sikap pemerintah daerah Provinsi Papua sangat tepat. Untuk itu diperlukan peran dari pelaku bisnis (pemerintah, masyarakat dan swasta) lebih dioptimalkan dengan membuat kebijakan yang mampu meningkatkan produk wisata tersebut. Untuk memperkuat regulasi pariwisata bukan merupakan tanggungjawab pemerintah daerah saja, namun unsur-unsur terkait seperti pemerintah, masyarakat dan swasta menjadi mata rantai yang tidak bisa dipisahkan.

Sebagaimana hasil wawancara, bahwa pemerintah melestarikan dan ikut merawat lokasi wisata yang dikunjungi di masing-masing wilayahnya. Sejumlah objek wisata untuk ditata kembali. Di antaranya, Pantai Base-G, Pantai Hamadi, Danau Love, Pantai Depapre, Danau Sentani serta lainnya. Akses jalan menuju ke sejumlah tempat wisata juga sudah diperbaiki. Pemerintah belum menyiapkan semua nya sesuai standar dan kebutuhan sebagai tempat wisata. Penegasan ini sangat penting, mengingat pariwisata papua meski tidak termasuk dalam prioritas perencanaan, namun keberadaannya sangat penting untuk menjadi bagian dari menjaga keberlangsungan pelestarian sumber daya alam di Provinsi Papua. Pemerintah Daerah harus memberikan dukungan dan komitmen sepenuhnya atas segala pembangunan yang diselenggarakan oleh Pemerintah Pusat di dalam area pariwisata ini. Ego sektoral dan ego kepentingan harus dikesampingkan dengan menempatkan kepentingan masyarakat di atas segalanya. Hal ini dipandang sebagai langkah untuk mempercepat pembangunan pariwisata di Provinsi Papua (Haryanto, 2019).

Dengan demikian hasil kajian ini, mengidentifikasi masih rendahnya kualitas pariwisata di Provinsi Papua diakibatkan karena kurangnya pengembangan, pengelolaan, dan perawatan terhadap potensi wisata, keterbatasan sarana dan prasarana penunjang pariwisata juga merupakan penyebab masih rendahnya kualitas pariwisata. Oleh karena itu maka strategi pengembangan potensi wisata Provinsi Papua secara lebih rinci pada Tabel berikut ini :

Tabel 1.

Faktor Internal Dan Eksternal Pengembangan Potensi Wisata Alam Di Provinsi Papua

\begin{tabular}{cc} 
& \multicolumn{2}{c}{ Faktor Internal } \\
Kekuatan (S) & Kelemahan (W) \\
\hline $\begin{array}{c}\text { Memiliki potensi wisata } \\
\text { alam }\end{array}$ & $\begin{array}{c}\text { Kurangnya promosi destinasi } \\
\text { wisata }\end{array}$ \\
\hline $\begin{array}{c}\text { Tersedianya festival } \\
\text { wisata alam }\end{array}$ & $\begin{array}{c}\text { Belum tersedianya Rencana } \\
\text { Induk Pariwisata Daerah } \\
\text { (RIPDA) Provinsi Papua }\end{array}$ \\
\hline $\begin{array}{c}\text { Tersedia sarana dan } \\
\text { prasarana Pendukung } \\
\text { objek wisata alam }\end{array}$ & $\begin{array}{c}\text { Pengelolaan objek wisata } \\
\text { alam belum secara } \\
\text { professional }\end{array}$ \\
\hline Faktor Eksternal \\
\hline $\begin{array}{c}\text { Peluang (O) } \\
\text { Meningkatnya jumlah } \\
\text { wisatawan }\end{array}$ & $\begin{array}{c}\text { Pudarnya budaya lokal/nilai } \\
\text { kearifan oleh budaya luar }\end{array}$ \\
\hline $\begin{array}{c}\text { Meningkatnya } \\
\text { Pendapatan masyarakat }\end{array}$ & $\begin{array}{c}\text { Meningkatnya migrasi ke } \\
\text { Papua }\end{array}$ \\
\hline $\begin{array}{c}\text { Meningkatnya } \\
\text { Pendapatan Asli Daerah } \\
\text { (PAD) }\end{array}$ & Kondisi keamanan belum \\
stabil
\end{tabular}

Merujuk tabel di atas, semua faktor yang telah ditentukan sebagai dasar penyusunan strategi pengembangan potensi wisata alam di Provinsi Papua, maka selanjutnya dalam merumuskan strategi kebijakan maka semua faktor internal dan eksternal utama seperti yang disajikan pada Tabel di atas. Dengan menggunakan faktor-faktor utama kekuatan (S), kelemahan (W), peluang (O) dan ancaman $(\mathrm{T})$, maka disusunlah rumusan strategi kebijakan pengembangan potensi wisata alam menjadi 4 strategi yaitu strategi S-O, W-O, S-T, dan W-T disajikan pada Tabel 2. Terkait tabel di atas, maka analisa SWOT nya sebagai berikut

\section{A. Strategi S - T (Kekuatan dan Ancaman)}

Strategi yang diambil adalah Pertama meningkatkan kualitas dan kuantitas promosi wisata. Strategi ini diperlukan karena pertimbangan letak geografis Provinsi Papua yang cukup strategis yang dapat mempermudah masuknya wisatawan ke Provinsi Papua sehingga diperlukan upaya promosi pariwisata semaksimal mungkin. Berdasarkan hasil penelitian bahwa sistem promosi pariwisata di Provinsi Papua masih terbatas pada pembuatan 
Tabel 2.

Matriks SWOT Strategi Pengembangan Pariwisata di Provinsi Papua

\begin{tabular}{|c|c|c|}
\hline INTERNAL & $\begin{array}{l}\text { KEKUATAN (STRENGTHS) : } \\
\text { Memiliki potensi wisata alam }\end{array}$ & $\begin{array}{l}\text { KELEMAHAN (WEAKNESS) } \\
\text { Kurangnya promosi destinasi wisata } \\
\text { Belum tersedianya Rencana Induk Pari- }\end{array}$ \\
\hline EKSTERNA & $\begin{array}{l}\text { Tersedia sarana dan prasarana Pen- } \\
\text { dukung objek wisata alam }\end{array}$ & $\begin{array}{l}\text { Pengelolaan objek wisata alam belum } \\
\text { secara professional }\end{array}$ \\
\hline $\begin{array}{l}\text { PELUANG (OPORTUNITIES) } \\
\text { Meningkatnya jumlah wisatawan } \\
\text { Meningkatnya Pendapatan mas- } \\
\text { yarakat } \\
\text { Meningkatnya PAD }\end{array}$ & $\begin{array}{l}\text { STRATEGI S-O : } \\
\text { Mengembangkan dan meningkatkan } \\
\text { kualitas pengelolaan produk wisata alam } \\
\text { secara profesional } \\
\text { Merancang pengelolaan Kegiatan } \\
\text { tahunan festival wisata alam yang } \\
\text { berkelanjutan }\end{array}$ & $\begin{array}{l}\text { STRATEGI W-O : } \\
\text { Meningkatkan kualitas dan kuantitas } \\
\text { promosi wisata } \\
\text { Mendorong pengembangan potensi wisa- } \\
\text { ta alam yang dapat memberikan dampak } \\
\text { secara ekonomi (multiplier effeck) }\end{array}$ \\
\hline $\begin{array}{l}\text { ANCAMAN (THREATS) } \\
\text { Pudarnya budaya local/nilai kearifan } \\
\text { oleh budaya luar } \\
\text { Meningkatnya migrasi ke Papua } \\
\text { Kondisi keamanan belum stabil }\end{array}$ & $\begin{array}{l}\text { STRATEGI S-T : } \\
\text { Memelihara budaya dan nilai kearifan } \\
\text { lokal } \\
\text { Menata data kependuduk terkait arus } \\
\text { migrasi yang makin meningkat }\end{array}$ & $\begin{array}{l}\text { STRATEGI W-T: } \\
\text { Menjaga dan memelihara potensi wisata } \\
\text { alam agar tidak punah/rusak } \\
\text { Menciptakan rasa aman bagi para wisa- } \\
\text { tawan yang berkunjung ke Papua }\end{array}$ \\
\hline
\end{tabular}

leaflet dan booklet serta keikutsertaan dalam pameran-pameran kebudayaan dan pariwisata baik ditingkat provinsi maupun tingkat nasional. Upaya promosi melalui teknologi informasi juga telah dilakukan, walaupun promosi tersebut masih terdapat beberapa kelemahan dalam penggunaan website yang disediakan oleh pemerintah, namun penggunaan teknologi informasi yang telah dilakukan telah memuat beberapa potensi wisata di Provinsi Papua sehingga masyarakat dapat mengetahui potensi wisata di Provinsi Papua dengan membuka website tersebut. Informan yang berada di Dinas Pariwisata menegaskan bahwa untuk memenuhi inovasi tersebut perlu mempertimbangkan konsep ramah lingkungan seperti pencanangan investasi hijau.

Kedua, Mendorong pengembangan potensi wisata alam yang dapat memberikan dampak secara ekonomi (multiplier effect). Strategi pengembangan potensi wisata alam juga diarahkan pada pengelolaan potensi wisata tersebut dapat memberikan dampak secara ekonomi berupa efek ganda. Jadi bukan hanya masyarakat pengelola lokasi wisata yang merasakan dampak ekonomi, tetapi juga dirasakan dan dinikmati oleh kelompok pelaku ekonomi lain seperti para penjual makanan, souvenir, perhotelan, jasa angkutan dan sebagainya. Untuk itulah menjadi perhatian bersama dalam memajukan pariwisata di Papua.

\section{B. Strategi S - T (Kekuatan dan Ancaman)}

Strategi yang bersumber dari strenghts dan threats ini merupakan sebuah strategi yang diciptakan dengan menggunakan kekuatan yang bersumber dari lingkungan internal untuk mengatasi ancaman dari lingkungan eksternal dalam pengembangan pariwisata di Provinsi Papua. Strategi yang diambil adalah: Pertama, memelihara budaya dan nilai kearifan lokal, meningkatnya jumlah wisatawan yang masuk ke Papua tentu saja perlu diimbangi dengan bagaimana menjaga nilainilai budaya yang ada pada masyarakat dengan cara mempertahankan dan nilai kearifan lokal. Hal ini diperlukan karena pengaruh budaya global dewasa ini sudah sangat kuat sehingga jika budaya lokal tidak dijaga maka lambat laun akan hilang. Untuk itu diperlukan adanya strategi memelihara budaya lokal agar tidak hilang melalui pelaksanaan Kegiatankegiatan festival budaya yang berkelanjutan yang selama ini sudah mulai dilaksanakan.

Kedua, Menata data kependuduk terkait arus migrasi yang makin meningkat. Berkembangnya sektor pariwisata di suatu wilayah sudah tentu akan berdampak terhadap arus migrasi, untuk itu diperlukan adanya penataan data kependudukan yang lebih ketat terhadap keluar masuknya penduduk di Provinsi Papua karena hal ini jika dibiarkan maka akan berpengaruh terhadap stabilistas kehidupan masyarakat yang ada di Provinsi Papua.

\section{Strategi W - T (Kelemahan-Ancaman)}

Strategi yang bersumber dari weakness dan threats ini merupakan sebuah strategi yang diciptakan dengan meminimalisir kelemahan yang bersumber dari lingkungan internal dan juga digunakan untuk menghindari ancaman dari lingkungan eksternal dalam pengembangan potensi wisata alam di Provinsi Papua. Strategi yang diambil adalah sebagai berikut: Pertama Menjaga 
dan memelihara potensi wisata alam agar tidak punah/rusak. Strategi ini dperlukan dalam rangka bagaimana menjaga dan melestarikan potensi wisata alam yang ada di Papua agar tidak rusak, cara menangkap ikan dengan menggunakan bom juga dihentikan karena dapat merusak terumbu karang dan habitat laut lainnya. Begitu juga dengan tempat wisata pantai dan danau agar tetap di jaga agar tidak rusak dan tetap menjadi potensi daya tarik wisata di Provinsi Papua yang luar biasa.

Kedua, menciptakan rasa aman bagi para wisatawan yang berkunjung ke Papua. Permasalahan klasik di Papua adalah masalah keamanan, untuk itu diperlukan strategi bagaimana menciptakan rasa aman bagi para wisatawan yang mau berkunjung ke Papua, untuk itu maka perlu disediakan pos-pos keamanan pada setiap titik tertentu yang setiap saat dapat memantau aktifitas para wisatawan yang sedang berkunjung di setiap lokasi wisata. Kondisi yang ada sekarang belum terlihat adanya pos-pos keamanan pada setiap lokasi wisata alam yang ada di Papua. Berdasarkan analisa SWOT, penulis akan menggambarkan alur strategi pengembangan pariwisata di Provinsi Papua pada gambar 3.

Alur pengembangan strategi dimulai dari penguatan regulasi di bidang pariwisata Papua. Meski Provinsi Papua sudah memiliki Peraturan Gubernur No 43 Tahun 2016 tentang Organisasi dan Tata kerja Dinas Pariwisata Provinsi Papua, namun implementasinya Provinsi Papua masih terkendala dalam pengembangan pariwisata di Papua. Penguatan regulasi diperlukan ketika sebuah daerah dihadapkan pada sebuah kebijakan mana yang banyak permasalahan, mana yang harus menjadi prioritas, membutuhkan dukungan regulasi di dalamnya. Seperti halnya permasalahan pariwisata di Provinsi Papua, membutuhkan dukungan regulasi yang kuat untuk mengembangkan pariwisata Papua agar dapat bersaing dengan daerah lainnya. Hal ini dimaklumi mengingat Peraturan Gubernur hanya menjelaskan mengenai posisi Organisasi dan Tata Kerja OPD terkait, bukan merupakan regulasi yang mengandung unsur pengembangan kepariwisataan Provinsi Papua. Bila penulis ingin membandingkan dengan Provinsi Papua Barat, daerah tersebut sudah membuat Peraturan Daerah No 13 Tahun 2013 tentang Kepariwisataan yang di dalamnya mengulas usaha pariwisata, pemberdayaan masyarakat, pembinaan kepariwisataan dan lainlain. Dari kedua lokasi tersebut terlihat jelas perbedaan perkembangan pariwisatanya, bahkan dengan regulasi yang kuat berpengaruh terhadap kepercayaan masyarakat. Contohnya Raja Ampat yang berada di Provinsi Papua Barat jauh lebih dikenal masyarakat daripada pariwisata yang ada di Provinsi Papua.

Sebelum melakukan pengembangan pariwisata, perlu memperhatikan kearifan lokal.
Sikap ini menjadi penting ketika kearifan lokal masih dipertimbangkan. Artinya kearifan lokal dengan kekayaan peraturannya akan memberikan rambu-rambu bagi wisatawan domestik maupun mancanegara untuk mentaatinya. Selain melihat regulasi, pengembangan pariwisata tidak bisa terlepas dari manajemen pengelolaan pariwisata. Bagaimana mewujudkan manajemen pariwisata yang lebih profesional. Mulai dari atensi untuk memperbaiki sarana dan parasarana wisata, penyediaan sumber daya manusia, maupun upaya promosi wisata baik itu melalui pemanfaatan media sosial, media elektronik maupun media massa untuk meningkatkan iklim kepercayaan masyarakat baik nasional maupun internasional. Perlu adanya optimalisasi penyiapan sarana dan prasarana untuk mendukung pengembangan wisata (Hidayat, 2016). Manajemen pengelolaan ini juga tidak bisa berpaling dari keterlibatan para OPD yang relevan seperti Dinas Pariwisata dan Ekonomi Kreatif, Dinas Koperasi dan UMKM, Dinas Perdagangan dan Dinas Perhubungan. OPD ini nantinya yang akan memberikan dukungan baik dalam penganggaran, pembentukan SDM yang kompeten maupun penyediaan sarana prasaran sebagai wujud atensi pemerintah daerah terhadap pariwisata.

Tak hanya itu, inovasi bidang pariwisata turut andil dalam mengembangkan pariwisata di Provinsi Papua. Untuk mewujudkan keberhasilan pelaksanaan inovasi dibutuhkan manajemen yang baik (Ratna Sari, 2019). Manajemen sebagai suatu proses yang khas terdiri dari tindakantindakan perencanaan, pengorganisasian, penggerakan dan pengendalian yang dilakukan untuk menentukan serta mencapai sasaran-sasaran yang telah ditentukan melalui pemanfaatan sumber daya manusia dan sumbersumber lainnya. Seperti aspek inovasi yang dapat dilihat adalah dari sisi kebaruan. Perubahan yang terjadi setidaknya dapat memiliki ciri khas dari Provinsi Papua. Khususnya dalam hal promosi wisata, hal-hal apa saja yang akan ditampilkan dan informasi yang akan disampaikan dalam pengembangan pariwisata. Tentunya dengan tidak meninggalkan budaya lokal yang ada.

Seperti penataan layout taman dengan menciptakan taman bukan hanya sarana hiburan tetapi juga sarana edukasi untuk masyarakat setempat. Selain itu, penyediaan transportasi darat ke tempat wisata kerja sama dengan Dinas Perhubungan. Setidaknya sarana transportasi dapat diakses oleh pengunjung dengan mudah dan cepat. Kemudian, sosialisasi melalui media massa/ elektronik, media sosial terkait keunggulan wisata Provinsi Papua, pemberdayaan UMKM di sekitar objek wisata, misalnya bekerja sama para pengrajin di provinsi Papua. OPD dapat memberikan pelatihan kepada para pengrajin atau pelaku usaha bagaimana 


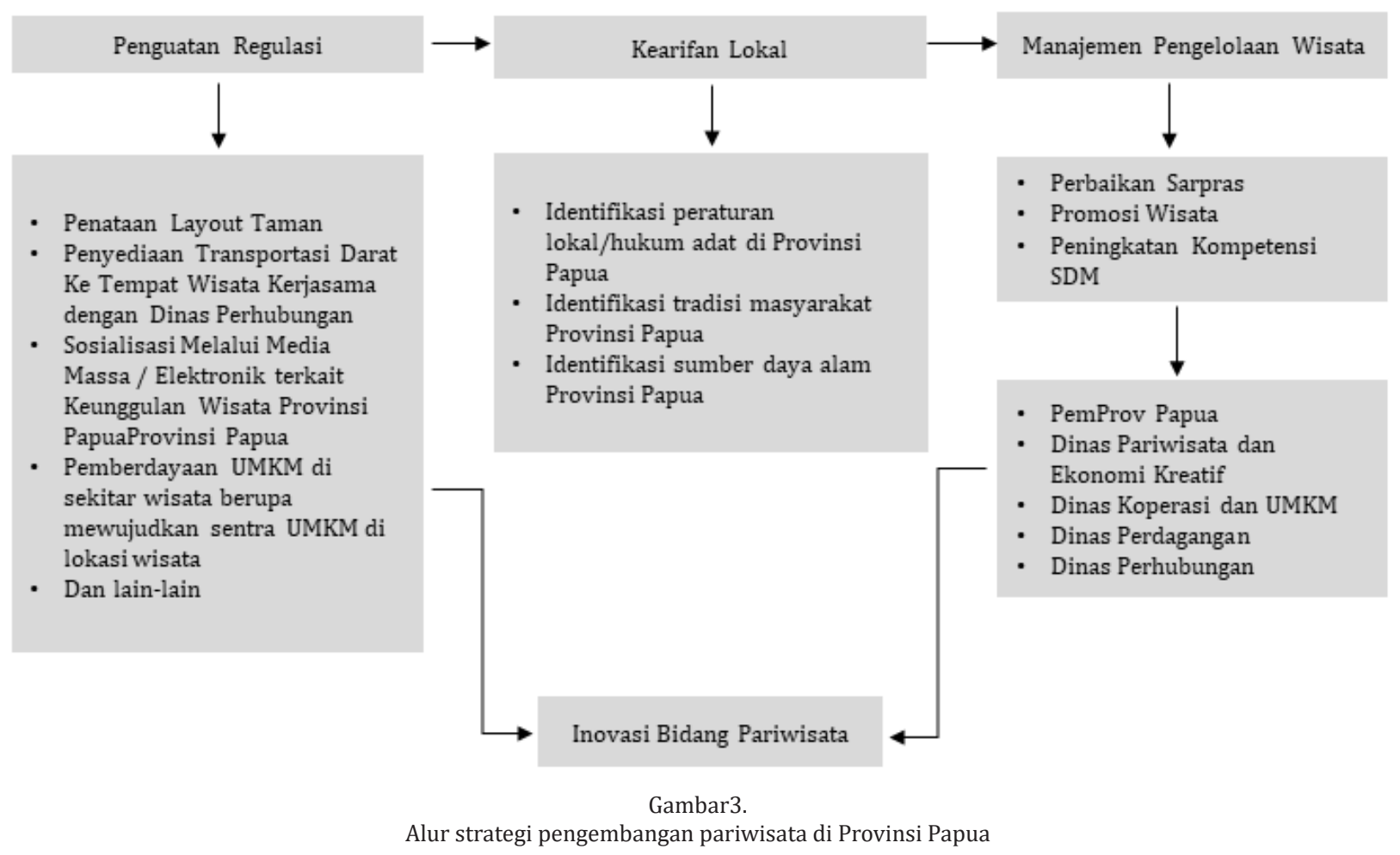

mengemas produk olahan dengan baik, strategi pemasaran yang menarik pengunjung dan pelaku usaha tidak segan untuk melakukan koordinasi dengan perangkat daerah yang terkait.

\section{KESIMPULAN}

Pengelolaan potensi pariwisata di Provinsi Papua pada umumnya masih secara tradisional dan dilakukan secara langsung oleh masyarakat pemilik hak ulayat atas tanah yang menjadi lokasi wisata tersebut. Kurangnya peran pemerintah maupun sektor swasta dalam mendukung pengembangan potensi wisata di provinsi Papua yang di tandai dengan belum tersedianya Rencana Induk Pariwisata Papua (RIP Papua) sebagai konsep dasar pengembangan pariwisata. Penyelengaraan promosi wisata tahunan melalui kegiatan fetival wisata alam dan budaya di provinsi Papua terkesan hanya kegiatan rutinitas dari tahun ke tahun sehingga kurang memberikan dampak yang signifikan bagi peningkatan keseahteraan masyarakat yang berdomisili di sekitar wilayah objek.

Saran yang dapat penulis sampaikan terkait pengembangan pariwisata di Provinsi Papua yaitu: (1) Mengembangkan dan meningkatkan kualitas pengelolaan produk wisata alam secara profesional melalui penerapan replikasi inovasi bidang pariwisata di daerah Provinsi Papua Barat, (2) Merancang pengelolaan kegiatan tahunan festival wisata alam yang berkelanjutan. (3) Meningkatkan kualitas dan kuantitas promosi wisata melalui peran media sosial/media massa/media elektronik , (4) Mendorong pengembangan potensi wisata alam untuk dapat memberikan dampak secara ekonomi (multiplier effect) seperti mengembangkan UMKM di sekitar lokasi wisata, (5) Memelihara unsur budaya dan nilai kearifan lokal seperti membuat musium peninggalan sejarah Papua, (7) Menciptakan rasa aman, nyaman dan mudah bagi para wisatawan yang berkunjung ke Papua seperti penyediaan transportasi yang menghubungan ke tempat wisata, dan (8) menyusun Peraturan Gubernur tentang Kepariwisataan yang di dalamnya terdapat konteks pengembangan manajemen pariwisata.

\section{UCAPAN TERIMA KASIH}

Kajian ini merupakan upaya penulis untuk mempercepat pembangunan pariwisata di provinsi Papua. Kami tidak lupa mengucapkan terima kasih kepada Ray Septianis Kartika yang telah memberikan arahan dan masukan untuk menyempurnakan hasil tulisan ini. Semoga yang sudah kami laporkan dalam tulisan ini dapat memberikan manfaat bagi masyarakat yang membacanya.

\section{Daftar Pustaka}

Agmasari, S. (2019). Daftar Wisatawan Mancanegara Paling Banyak Berkunjung ke Indonesia 2019. Kompas.Com. https://travel.kompas.com/ read/2019/11/03/164641027/daftarwisatawan-mancanegara-paling-banyakberkunjung-ke-indonesia-2019

Atmoko, T. P. H. (2014). Strategi Pengembangan Potensi Desa Wisata Brajan Kabupaten Sleman. Media Wisata, 12(2), 146-154. https://doi. org/10.36276/mws.v12i2.87 
bappenas. (2019). Musrenbangnas 2019 RKP 2020: Peningkatan SDM untuk Pertumbuhan Berkualitas. Bappenas.Go.Id. https://www. bappenas.go.id/id/berita-dan-siaran-pers/ musrenbangnas-2019-rkp-2020-peningkatansdm-untuk-pertumbuhan-berkualitas /

Ervina. (2017). Penerapan Strategi Pengembangan Pariwisata oleh Dinas Pariwisata di Kabupaten Kutai Kartanegara. EJournal Administrasi Negara, 5(3), 6240-6254. http://ejournal. an.fisip-unmul.ac.id/site/wp-content/ uploads/2017/07/JURNAL (07-20-17-02-1418).pdf.

Fahmi, I., \& Yunus, M. (2013). Manajemen Strategis: Teori dan Aplikasi. Alfabeta. https://doi. org/978-602-7825-54-3

Flo, E. (2018). Promosi Wisata Papua, Gempi Siap Gebrak Media Sosial. Merahputih.Com. https:// merahputih.com/post/read/promosi-wisatapapua-gempi-siap-gebrak-media-sosial

Haryanto, J. T. (2019). Kesesuaian Kegiatan Dana Alokasi Khusus (DAK) Pariwisata dan Permasalahan Pariwisata di Indonesia. Matra Pembaruan, 3(1), 25-36. https://doi. org/10.21787/mp.3.1.2019.25-36

Hidayat, M. (2016). Strategi Perencanaan dan Pengembangan Objek Wisata (Studi Kasus Pantai Pangandaran Kabupaten Ciamis Jawa Barat). The Journal: Tourism and Hospitality Essentials Journal, 1(1), 33-44. http://ejournal. upi.edu/index.php/thejournal/article/ view/1879

Itamar, H., Alam, A. S., \& Rahmatullah, R. (2014). Strategi Pengembangan Pariwisata di Kabupaten Tana Toraja. GOVERNMENT : Jurnal Ilmu Pemerintahan, 7(2), 91-108. http:// journal.unhas.ac.id/index.php/government/ article/view/1248

Loen, A. (2019). Musrenbang Provinsi Papua usulkan 2.139 program. Jubi.Co.Id. https://jubi.co.id/ musrenbang-provinsi-papua-usulkan-2-139program/

Nurhadi, F. D. C., Mardiyono, \& Rengu, S. P. (2014). Strategi Pengembangan Pariwisata Oleh Pemerintah Daerah Terhadap Pendapatan Asli Daerah (PAD) (Studi Pada Dinas Pemuda, Olahraga, Kebudayaan Dan Pariwisata Kabupaten Mojokerto). Jurusan Administrasi Publik, 2(2), 325-331. https://www.neliti. com/id/publications / $77667 /$ strategi pengembangan-pariwisata-oleh-pemerintahdaerah-terhadap-pendapatan-asli

Nurhayati, S., \& Ristanto, V. G. (2017). Sistem Informasi Pariwisata Provinsi Papua Berbasis Web. Seminar Nasional APTIKOM (SEMNASTIKOM), 302-308. https://
www.academia.edu/35977356/SISTEM_ INFORMASI_PARIWISATA_PROVINSI_PAPUA_ BERBASIS_WEB

papuabangkit.com. (2017). Pemprov Dorong Pariwisata Berbasis Ekonomi Lokal. Papuabangkit.Com. https://www. papuabangkit.com/2017/03/15/pemprovdorong-pariwisata-berbasis-ekonomi-lokal/

Pathurrahman. (2015). Strategi Dinas Kebudayaan dan Pariwisata Kabupaten Lombok Timur dalam Promosi Pariwisata pada Tahun 2014 [Universitas Muhammadiyah Yogyakarta]. http://repository.umy.ac.id/ handle/123456789/18452

Petriella, Y. (2018). Pengembangan Pariwisata: Fokus Harus Diarahkan ke Papua. Bisnis.Com. https://sumatra.bisnis. com/read/20181012/448/848311/ pengembangan-pariwisata-fokus-harusdiarahkan-ke-papua

Pieda, G. C. D. R. C. da, \& Anom, I. P. (2019). Dampak Ekonomi Pengembangan Daya Tarik Wisata "Hot Spring" Di Kecamatan Marobo, Kabupaten Bobonaro, Timor-Leste. Jurnal Destinasi Pariwisata, 7(2), 226-230. https:// doi.org/10.24843/JDEPAR.2019.v07.i02.p03

Pitana, I. G., \& Diarta, I. K. S. (2009). Pengantar Ilmu Pariwisata (Cet.1). Andi.

Prakoso, J. R. (2015). Ini Masalah yang Membuat Pariwisata Papua Tidak Berkembang. Detik.Com. https://travel.detik.com/ travel-news / d-2947632/ini-masalahyang-membuat-pariwisata-papua-tidakberkembang

Prantawan P, D. G. A., \& Sunarta, I. N. (2015). Studi Pengembangan Desa Pinge sebagai Daya Tarik Ekowisata di Kecamatan Marga Kabupaten Tabanan. Jurnal Destinasi Pariwisata, 3(1), 1-88. https://doi.org/10.24843/JDEPAR.2015. v03.i01.p01

Primadany, S. R. (2013). Analisis Strategi Pengembangan Pariwisata Daerah (Studi pada Dinas Kebudayaan dan Pariwisata Daerah Kabupaten Nganjuk). Jurnal Administrasi Publik, 1(4), 135-143. http:// administrasipublik.studentjournal.ub.ac.id/ index.php/jap/article/view/126

Ratna Sari, Y. (2019). Manajemen Retribusi Pasar Melalui Inovasi Tape Pasar di Kota Surakarta. Matra Pembaruan, 3(1), 13-23. https://doi. org/10.21787/mp.3.1.2019.13-23

Rumpaidus, G. A., Putra, A. M., \& Widyatmaja, I. G. N. (2019). Strategi Pengembangan Destinasi Pariwisata Kabupaten Biak Numfor Provinsi Papua. Jurnal Kepariwisataan Dan Hospitalitas, 3(2), 22-42. https://ojs.unud.ac.id/index.php/ 
jkh/article/view/45903

Subardin, F. N., Firmansyah, \& Priyandoko, Z. (2010). Penentuan Prioritas Pengembangan Wisata Alam di Kabupaten Lebak [Universitas Pasundan]. ac.id/32088/
Suwantoro, G. (2004). Dasar-Dasar Wisata. Andi. TR01. (2019). Pemkab Batola Utamakan Skala Prioritas. Http://Abdipersadafm.Co.Id. http:// abdipersadafm.co.id/2019/04/02/pemkabbatola-utamakan-skala-prioritas/ 